\title{
Gerakan Makassar Tidak Rantasa
}

\author{
Yunita \\ Mas'ud Ibrahim \\ Universitas Muhammadiyah Makassar \\ masudibrahim@unismuh.ac.id \\ Syarifuddin \\ Universitas Muhammadiyah Makassar \\ syarifuddin@unismuh.ac.id
}

\begin{abstract}
ABSTRAK
Jenis penelitian yang digunakan adalah metode penelitian deskriptif kualitatif dengancara penentuan sampel melalui teknik Purposive Sampling dengan memilih beberapa informan yang memiliki kriteria yang telah ditentukan oleh peneliti. Penelitian ini bertujuan untuk mengetahui (1) Cara dinaskebersihankota Makassar dalam mensosialisasikan "Gerakan Makassar Tidak rantasa", (2) Bentuk partisipasi masyarakat terhadap "Gerakan Makassar Tidak Rantasa".Dari hasil penelitian menunjukkan Sosialisasi pemerintah pada program gerakan Makassar tidak rantasa adalah melalui sosialisasi MTR dari rumah kerumah (door to door) dan selain itu menggunakan brosurbrosur media cetak lainnya mengenai program MTR yang dilakukan oleh pemerintah kota makassar serta melibatkan camat dan lurah untuk turun serta dalam mensosialisasikan dengan memberikan pengarahan kepada warga mengenai masalah kebersihanserta bentuk partisipasi masyarakat yang berperan dalam pelaksanaan program MTR, dimana masyarakat menyediakan pot-pot bunga serta tempat sampah yang berada didepan rumah masing-masing guna untuk menjaga kebersihan masing-masing dan ikut sertanya masyarakat dalam kerja bakti yang diadakan pada satiap hari jumat.
\end{abstract}

Kata Kunci : Gerakan Sosial, Masyarakat, Makassar Tidak Rantasa.

\section{PENDAHULUAN}

Masalah kebersihan tidak kunjung selesai hampir di setiap kota di Indonesia. Permasalahan ini muncul setiap tahun dan terus berlangsung tanpa ada solusi yang tepat dalam pelaksanaannya.Kondisi perkotaan yang masih jauh dari predikat Kota bersih masih menjadi info yang populer diangkat oleh banyak media setiap harinya.Ketika sampah masih banyak berserakan dimana-mana kerap dianggap tidak sesuai dengan visi Kota yang sebagian besar menekankan aspek kebersihan, keindahan dan kerapihan Kota atau kita kenal dengan istilah 3K. Oleh karena itu kebersihan, keindahan dan kerapihan seringkali menjadi target utama kebijakan - kebijakan pemerintah kota.

Hal ini merupakan masalah yang sangat kompleks karena akan menghadapi banyak karakter atau perilaku masyarakat yang beragam. Perilaku masyarakat perkotaan yang relatif berbeda dalam menyikapi masalah kebersihan erat relevansinya dengan pendidikan atau pengetahuan tentang kesehatan yang tidak merata.Hal ini juga bisa dipengaruhi oleh kebiasaan masyarakat yang sudah berjalan dalam waktu yang lama 
tanpa adanya aturan atau sanksi yang bisa membuat jera.Masyarakat yang mempunyai kebiasaan buang sampah bukan pada tempatnya membuat kondisi Kota menjadi memprihatinkan baik dari segi kebersihan, keindahan dan kerapihanbegitupun dengan kesehatan masyarakat pada umumnya.

Dimulai dari Tata kelolah pemerintahan yang baik (good governance) yang merupakan salah satu konsep yang dijalankan oleh satu daerah dalam rangka pencapaian tujuan negara/daerah.Tak hanya sampai disitu seiring dengan perkembangan ilmu pengetahuan, maka telah muncul beberapa konsep dan paradigma baru dalam memenuhi kebutuhan masyarakat secara cepat dan terbuka. Salah satu diantaranya adalah penerapan teknologi dalam bidang pemerintahan atau biasa disebut dengan electronic government (e-government).“E-Governmentadalah sebuah cara bagi pemerintahan untuk menggunakan sebuah teknologi baru untuk melayani masyarakat dengan memberikan kemudahan akses untuk pemerintah dalam hal pelayanan dan informasi dan juga untuk menambah kualitas pelayanan serta memberikan peluang untuk berpartisipasi dalam proses dan institusi birokrasi Pemerintah. (Andrianto, 2007:46). Dimana dalam pelaksanaan e-government memiliki enam asas dalam pelaksanaannya yaitu Transparan, Akuntabilitas. Kondisional, Partisipatif. Kesamaan hak dan Keseimbangan hak.Akan tetapai tak cukup sampai disitu penerapan e-government telah berkembang dengan munculnya konsep baru yaitu smart city.

Berangkat dari permasalahan ini dan survey di lapangan, maka Walikota Makassar membuat kebijakan Makassar Tidak Rantasa (MTR).Sebagai bentuk solusi untuk menangani permasalahan kebersihan yang ada.Manusia setiap harinya menghasilkan sampah baik itu sampah organic maupun sampah anorganik.Sistem persampahan memiliki tahap-tahap dalam pengaplikasian sehari-hari, tahap pertama ialah tahap timbulan, tahap kedua ialah tahap perwadahan, tahap ketiga ialah tahap pengumpulan, tahap keempat ialah pengangkutan dan tahap pengolahan kembali serta tahap kelima ialah tahap pembuangan akhir. Seiring dengan berkembangnya kota Makassar maka perkembangan penduduk Kota Makassar pun akan semakin meningkat, hal tersebut tentu saja meningkatkan jumlah timbulan sampah yang dihasilkan oleh masyarakat Kota Makassar.

Kebijakan-kebijakan yang menangani masalah persampahan ialah dengan melakukan pembinaan dan penanganan terhadap masalah-masalah yang terjadi di Kota Makassar. Peranan kelembagaan Kota Makassar yang telah berlangsung menurut dinas PLHK berupa: Program tidak rantasa yang dilaksanakan guna mendukung program Kota 
Makassar Sehat. Untuk mengatasi masalah kebersihan Kota Makassar maka Pemerintah Kota (Pemkot) Makassar melakukan gerakan revolusi kebersihan di bawah kepemimpinan Walikota dan Wakil Walikota Makassar, Moh Ramdhan Pomanto dan Syamsu Rizal.Maka dikeluarkanlah kebijakan yang disebut dengan "Makassar Tidak Rantasa".Kebijakan ini mulai diperkenalkan didepan warga Kota Makassar pada tanggal 15 Juni 2014.Kebijakan Makassar Tidak Rantasa merupakan kebijakan yang mengatur tentang tata kebersihan Kota dimulai dari kesadaran semua warga Kota.Makassar untuk mengedepankan aspek kebersihan dalam kehidupan sehari-hari.Perilaku sebagian masyarakat yang sudah terbiasa melakukan pembiaran terhadap pola hidup tidak bersih menjadikan mereka tidak merespon kebijakan-kebijakan terkait dengan kebersihan atau kesehatan yang sudah ada.Alternatif kebijakan yang kami tawarkan adalah kebijakan tentang pentingnya memelihara kebersihan disertai dengan adanya efek jera kepada masyarakat yang biasanya tidak disiplin untuk lebih sadar dalam penerapan pola hidup sehat.

\section{LANDASAN TEORI}

Menurut Soerjono Soekanto dalam buku Burhan Bugin (2006 : 31), sosiologi komunikasi merupakan sosiologi yang mempelajari interaksi sosial yaitu suatu hubungan atau komunikasi yang menimbulkan proses saling pengaruh-mempengaruhi antara para individu, individu dengan kelompok maupun antar kelompok. Bennard Berelson dan Gary A. Steinner dalam buku Wiryanto (2004:7) mendefenisikan komunikasi adalah transmisi informasi, gagasan, emosi, keterampilan, dan sebagainya, tindakan atau proses transmisi.Komunikasi berkembang sejalan dengan perkembangan masyarakat, mulai dari masyarakat kecil dalam bentuk keluarga sampai masyarakat besar seluas dengan negara dan seluas dunia.Maka selain pemerintah, komunikasi berati pula pengumuman, penerangan, penyuluhan, perintah, instruksi, komando, nasehat, ajakan, bujukan, rayuan, dan sebagainya. Komunikasi tidak lagi merupakan upaya agar seseorang tahu, tetapi juga ia melakukan sesuatu atau melaksanakan kegiatan tertentu. Strategi komunikasi erat hubungannya antara tujuan yang hendak dicapai dengan konsekuensi - konsekuensi (masalah) yang harus diperhatikan, kemudian merencanakan bagaimana.

Konsekuensi - konsekuensi sesuai dengan hasil yang diharapkan atau tujuan yang akan dicapai strategi pada hakikatnya adalah suatu perencanaan (planning) dan manajemen (management) untuk mencapai suatu tujuan. Akan tetapi, untuk mecapai tujuan tersebut, strategi tidak berfungsi sebagai peta jalan yang hanya menunjukkan arah 
saja, melainkan harus mampu menunjukkan bagaimana taktik operasionalnya.Ada empat tujuan dalam strategi komunikasi sebagai berikut : (1) To Secure Understanding yaitu untuk memastikan bahwa terjadi suatu pengertian dalam berkomunikasi. (2) To Establish Acceptance, yaitu bagaimana cara penerimaan itu terus dibina dengan baik. (3) To Motivate Action yaitu penggiatan untuk memotivasinya, dan (4) To Goals Which Communicator Sought To Achieve yaitu bagaimana mencapai tujuan yang hendak dicapai oleh pihak komunikator dari proses komunikasi tersebut.

Banyak ahli memberikan pengertian mengenai konsep partisipasi. Bila dilihat dari asal katanya, kata partisipasi berasal dari kata bahasa Inggris "participation" yang berarti pengambilan bagian, pengikutsertaan (John M. Echols \& Hasan Shadily, 2000: 419). Partisipasi berarti peran serta seseorang atau kelompok masyarakat dalam proses pembangunan baik dalam bentuk pernyataan maupun dalam bentuk kegiatan dengan memberi masukan pikiran, tenaga, waktu, keahlian, modal dan atau materi, serta ikut memanfaatkan dan menikmati hasil -hasil pembangunan (I Nyoman Sumaryadi, 2010: 46). Pengertian tentang partisipasi dikemukakan oleh Fasli Djalal dan Dedi Supriadi, (2001: 201-202) dimana partisipasi dapat juga berarti bahwa pembuat keputusan menyarankan kelompok atau masyarakat ikut terlibat dalam bentuk penyampaian saran dan pendapat, barang, keterampilan, bahan dan jasa. Partisipasi dapat juga berarti bahwa kelompok mengenal masalah mereka sendiri, mengkaji pilihan mereka, membuat keputusan, dan memecahkan masalahnya.H.A.R.Tilaar, (2009: 287) mengungkapkan partisipasi adalah sebagai wujud dari keinginan untuk mengembangkan demokrasi melalui proses desentralisasi dimana diupayakan antara lain perlunya perencanaan dari bawah (bottom-up) dengan mengikutsertakan masyarakat dalam proses perencanaan dan pembangunan masyarakatnya. Menurut Sundariningrum dalam Sugiyah (2001: 38) mengklasifikasikan partisipasi menjadi 2 (dua) berdasarkan cara keterlibatannya, yaitu :

a. Partisipasi Langsung

Partisipasi yang terjadi apabila individu menampilkan kegiatan tertentu dalam proses partisipasi. Partisipasi ini terjadi apabila setiap orang dapat mengajukan pandangan, membahas pokok permasalahan, mengajukan keberatan terhadap keinginan orang lain atau terhadap ucapannya.

b. Partisipasi tidak langsung

Partisipasi yang terjadi apabila individu mendelegasikan hak partisipasinya. Cohen dan Uphoff yang dikutip oleh Siti Irene Astuti D (2011: 61-63) 
membedakan patisipasi menjadi empat jenis, yaitu pertama, partisipasi dalam pengambilan keputusan. Kedua, partisipasi dalam pelaksanaan. Ketiga, partisipasi dalam pengambilan pemanfaatan. Dan Keempat, partisipasi dalam evaluasi.

Berdasarkan beberapa definisi di atas maka dapat disimpulkan bahwa partisipasi adalah keterlibatan suatu individu atau kelompok dalam pencapaian tujuan dan adanya pembagian kewenangan atau tanggung jawab bersama.

\section{METODE PENELITIAN}

Jenis penelitian yang dilakukan adalah penelitian deskriptif kualitatif yang bertujuan untuk memperoleh diskripsi yang utuh dan mendalam dari sebuah identitas. Dimana menghasilkan data untuk selanjutnya dianalisis untuk menghasilkan teori.Informan ditentukan secara purposive sampling, dan juga menggunakan sumber data primer dan data sekunder, teknik pengumpulan data yaitu observasi, wawancara, dokumentasidanangket, kemudian dianalisis melalui tahapan pengumpulan data (data collection), reduksi data (data reduction), penyajian data (display data), penarikan kesimpulan (verification).

\section{PEMBAHASAN}

Masalah kebersihan tidak kunjung selesai hampir di setiap kota di Indonesia. Permasalahan ini muncul setiap tahun dan terus berlangsung tanpa ada solusi yang tepat dalam pelaksanaannya.Kondisi perkotaan yang masih jauh dari predikat Kota bersih masih menjadi info yang populer diangkat oleh banyak media setiap harinya.Ketika sampah masih banyak berserakan dimana-mana kerap dianggap tidak sesuai dengan visi Kota yang sebagian besar menekankan aspek kebersihan, keindahan dan kerapihan Kota atau kita kenal dengan istilah $3 \mathrm{~K}$. Oleh karena itu kebersihan, keindahan dan kerapihan seringkali menjadi target utama kebijakan - kebijakan pemerintah kota.Manusia setiap harinya menghasilkan sampah baik itu sampah organic maupun sampah anorganik, sampah juga dapat mengakibatkan terjadinya letusan wabah penyakit, untuk di Kota Makassar sampah adalah masaalah yang cukup kompleks dan mempunyai pengaruh signifikan terhadap kesehatan (Abses dari pintu masuknya penyakit berbasis sampah). Sampah yang menjadi permasalahan di kota Makassar dapat diatasi dengan sikap dan tindakan yang bershabat dengan sampah, diantaranya partisipasi masyarakat, turut sertanya pihak kelembagaan (swasta) dan pemerintah agar permaslahan persampahan 
dapat teratasi secara menyeluruh.Sampah adalah bahan yang tidak mempunyai nilai atau tidak berharga untuk maksud biasa atau utama dalam pembikinan atau pemakaian barang rusak atau bercacat dalam pembuatan manufaktur atau materi berkelebihan atau ditolak atau buangan, (Kamus Istilah Lingkungan, 1994).

Untuk mengatasi masalah kebersihan Kota Makassar maka Pemerintah Kota (Pemkot) Makassar melakukan gerakan revolusi kebersihan di bawah kepemimpinan Walikota dan Wakil Walikota Makassar, Moh Ramdhan Pomanto dan Syamsu Rizal.Maka dikeluarkanlah kebijakan yang disebut dengan "Makassar Tidak Rantasa”.Kebijakan ini mulai diperkenalkan didepan warga Kota Makassar pada tanggal 15 Juni 2014.Kebijakan Makassar Tidak Rantasa merupakan kebijakan yang mengatur tentang tata kebersihan Kota dimulai dari kesadaran semua warga Kota.Makassar untuk mengedepankan aspek kebersihan dalam kehidupan sehari-hari.

Khusus lurah, bertugas sosialisasi Gemar MTR dari rumah ke rumah (door to door) melalui brosur-brosur, sebelum aksi aksi bersama.persoalan rantasa bukan hanya pada persoalan kebersihan, tetapi juga pada pola pikir dan perilaku."Ini akan menjadi langkah awal, untuk merubah pola pikir dan perilaku masyarakat Makassar untuk lebih disiplin dan peduli, dan ini tentunya harus dimulai dari para pemimpin. diharapkan mampu menekan terjadinya penumpukan sampah di seluruh tempat pembuangan sementara (TPS) seiring dengan pemberlakukan kebijakan jam operasional truk.

Kebijakan penanggulangan kebersihan yang dilaksanakan selama ini seperti melaksanakan sosialisasi tentang pentingnya kebersihan dan manfaatnya terhadap kesehatan sebagai langkah antisipatif agar timbulnya penyakit dapat dihindari serta dapat memberikan manfaat terhadap keindahan Kota.Namun hal tersebut sepertinya belum maksimal dikarenakan masih banyaknya sampah yang sering dijumpai disekitar kita.Hal tersebut terjadi disebabkan karena masih kurangnya kesadaran masyarakat untuk meningkatkan pola hidup sehat.

Dari pembahasan di atas permasalahan sampah yang dihadapi masyarakat kota Makassar dibutuhkan peran pemerintah dalam mensosialisasikan gerakan Makassar tidak rantasa serta bentuk partisipasi masyarakat terhadap gerakan makassar tidak rantasa, Menurut I Nyoman Sumaryadi, (2010: 46) bahwa Partisipasi berarti peran serta seseorang atau kelompok masyarakat dalam proses pembangunan baik dalam bentuk pernyataan maupun dalam bentuk kegiatan dengan memberi masukan pikiran, tenaga, waktu, keahlian, modal dan atau materi, serta ikut memanfaatkan dan menikmati hasil - hasil pembangunan. Dari teori yang dikemukakan oleh I Nyoman 
Sumaryadi, keikut sertanya baik itu pemerintah mauapun masyarakat dalam menyukseskan program MTR dimana keterlibatannya masyarakat dan pemerintah untuk menciptakan makassar yang bebas dari sampah.

Conyer dalam Soetomo, mengemukakan pastisipasi masyarakat adalah keikutsertaan masyarakat secara sukarela yang didasari oleh determinan dan kesadaran diri masyarakat itu sendiri dalam program pembangunan. Ada lima cara untuk melibatkan keikutsertaan masyarakat yaitu :

1. Survey dan konsultasi local untuk memperoleh data dan informasi yang diperlukan.

2. Memanfaatkan petugas lapangan, agar sambil melakukan tugasnya sebagai agen pembaharu juga menyerap berbagai informasi yang dibutuhkan dalam perencanaan.

3. Perencanaan yang bersifat desentralisasi agar lebih memberikan peluang yang semakin besar kepada masyarakat untuk berpartisipasi.

4. Perencanaan melalui pemerintah lokal.

5. Menggunakan strategi pembangunan komunikasi.

Teori yang dikemukakan oleh Conyer dalam soetomo menjelaskan bahwa masyarakat ataupun pemerintah ikut serta untuk melibatkan diri mereka dalam mensukseskan program MTR dimana dilandasi adanya kesadaran dari diri mereka sendiri.Houltmengemukakan bahwa partisipasi adalah suatu gejala keadaan sosiologi dimana seseorang merasakan bersama-sama dengan orang lain sebagai akibat dari terjadinya interaksi social. Berlangsungnya partisipasi masyarakat merupakan kegiatan antara dua pihak yakni pihak yang membangkitkan yaitu pemerintah, jadi bukan cuman kegiatan yang sepihak saja, dimana dalam kaitanya dengan pembangunan desa maka, pihak yang memegang peran dalam membangkitkan partisipasi mayarakat adalah peran dari pemerintah daerah, dalam upaya membangkitan partisipasi masyarakat, dimana komunikasi mempunyai peran penting dalam memelihara hubungan secara timbal balik, disatu pihak pemerintah menyampaikan kebijakan kepada masyarakat sendangkan di lain pihak masyarakat menyampaikan gagasan, keinginan atau kebutuhannya kepada pemerintah.

Berkaitan dengan program GTR ini pemerintah daerah mempunyai peran penting dalam melibatkan partisipasi masyarakat dimana komunikasi ini mempunyai peran penting dalam memelihatra hubungan antara pemerintah daerah dan masyarakat guna untuk menyelesaikan kendala-kendala yang dihadapi masyarakat dalam melaksanakan program GTR ini dimana untuk menjadiaka kota makassar menjadi kota dunia.Goldsmith 
dan Blustain dalam Ndraha mengemukakan bahwa masyarakat tergerak untuk berpartisipasi jika :

1. Partisipasi itu dilakukan melalui organisasi yang sudah dikenal atau yang sudah ada ditengah-tengah masyarakat.

2. Partisipasi itu memberikan manfaat langsung kepada masyarakat yang bersangkutan.

3. Manfaat yang diperoleh melalui partisipasi dapat memenuhi kepentingan masyarakat setempat.

4. Dalam proses partisipasi itu terjamin adanya kontrol yang dilakukan oleh masyarakat.

Dimana teori yang dijelaskan oleh Goldsmith dan Blustain dalam Ndraha bahwa partisipasi yang dilakukan masyarakat memberikan manfaat serta mengajak masyarakat untuk turut serta dalam menjalankan program MTR untuk mewujudkan tujuan yaitu dimana bertujuan menjadikan kota makassar menuju kota bersih, bebas dari sampah. Menurut Lasswell dalam Efendy mengatakan bahwaStrategi komunikasi adalah model atau formula yaitu :who, says what, in which channel, to whom, with what effect (siapa, berkata apa, melalui saluran apa, kepada siapa, dan bagaimana efeknya ), model komunikasi yang dapat digambarkan sebagai berikut:

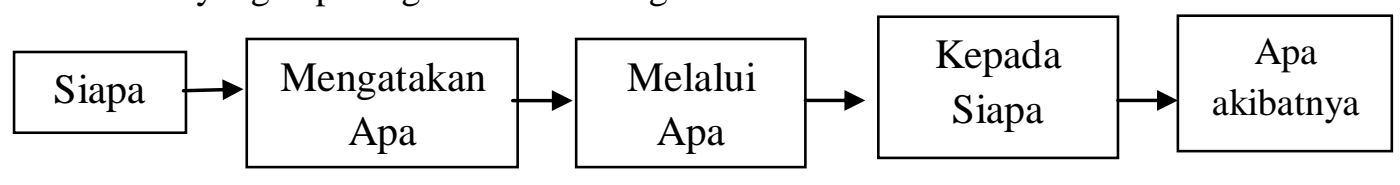

Dari penjelasan yang dikemukakan oleh Lasswel dalam Efendy bahwa (siapa) dimana pemerintah melakukan sosialisasi atau mengarahkan kepada masyarakat mengenai GTR ini, (mengatakan apa) pemerintah mngatakan maksud dan tujuan dari program GTR ini, (melalui apa) dimana perintah menjelaskan mengenai program GTR ini baik melalui media cetak ataupun brosur-brosur serta mengikutsertakan camat dan lurah dala sosialisasi tentang GTR, (kepada siapa) pemerintah memberikan pengarahan tentang GTR kepada masyarakat agar turut berpartispasi dalam menjalankan program ini, serta (apa akibatnya) dimana program GTR ini membawa dampak yang baik bagi masyarakat terutama dalam mengatasi masalah kebersihan.

\section{KESIMPULAN}

Setelah melakukan penelitian, maka peneliti dapat menyimpulkan beberapa kesimpulan untuk menjawab masalah yang diangkat dalam penelitian ini, kesimpulan yang dapat ditarik yaitu :

1. Peran pemerintah pada program gerakan Makassar tidak rantasa adalah : 
a. Melalui sosialisasi MTR dari rumah kerumah (door to door).

b. Menggunakan brosur- brosur media cetak lainnya mengenai program MTR yang dilakukan oleh pemerintah kota makassar.

c. Melibatkan para camat dan lurah untuk turun serta dalam mensosialisasikan dengan memberikan pengarahan kepada warga mengenai masalah kebersihan.

2. Bentuk partisipasi masyarakat yang berperan dalam pelaksanaan program MTR dimana masyarakat menyediakan pot-pot bunga serta tempat sampah yang berada didepan rumah masing-masing guna untuk mengaja kebersihan masing-masing dan ikut sertanya masyarakat dalam kerja bakti yang diadakan pada satiap hari jumat.

\section{DAFTAR PUSTAKA}

Abu Huraerah, (2008). Pengorganisasian dan Pengembangan Masyarakat Model dan Strategi Pembangunan Berbasis Kerakyatan. Bandung: Humaniora.

Andrianto, Nico. (2007). Transparansi dan Akuntabilitas Publik melalui E_Government.Malang: Bayumedia Publising.

Arifin, Anwar, (1994).Strategi Komunikasi; Sebuah Pengantar Ringkas, Bandung, Armico.

Arikunto, Suharsimi. (1998). Prosedur Penelitian : Suatu Pendekatan Praktek. Jakarta : Rineka Cipta.

Bugin, Burhan. (2006)Sosiologi Komunikasi. Jakarta: fajar interpratama mandiri.

Effendy, (1999). Ilmu Komunikasi: Teori dan Praktek, Bandung : Remaja Rosdakarya.

Jim Ife dan Frank Tesoreiro, (2008),.Alternatif Pengembangan Masyarakat di Era Globalisasi Community Development. Yogyakarta: Pustaka Pelajar.

Keraf, Sonny. (2002) Etika Lingkungan.Jakarta :Kompas.

Maleong, lexi J. (2007).Metode Penelitian Kualitatif. Penerbit PT Remaja Rosdakarya, Bandung.

Mulyana, Deddy. (2005). Ilmu Komunikasi: Suatu Pengantar. Bandung: Rosda.

Munarfah, M. Andi dan Hasan Muhammad.(2009). Metode Penelitian. Jakarta: CV. Praktika Aksara Semesta.

Oliver, Sandra .(2007). Strategi Public Relations. Jakarta: Erlangga.

Profil Wilayah Kantor KecamatanTamalate 2015.

Ruslan, Roesady.(1998). Manajemen Public Relations dan Media Komunikasi.Bandung: Raja Grafindo Persada. 
Sutanto, Astrid, (1988)Memasyarakatkan Ide-Ide Baru. Surabaya, Usaha Nasional.

Widjaja A.W. (1986). Komunikasi-Komunikasi dan Hubungan Masyarakat. Jakarta: Bina Aksara.

Wiryanto.(2004). Pengantar Ilmu Komunikasi.PT. Grasindo, Jakarta. 